\title{
Bleo-VEMF'HA 同調化学療法の試み
}

\author{
大川 正直・牧本 一男* - 山内 民男** \\ 飛田収一・高橋 陽一***
}

\section{Synchronized Chemotherapy with Bleomycin, Vincristine, Endoxan, Methotrexate, FH Predonin and Adriamycin (Bleo-VEMF'HA)}

\author{
Masanao Ohkawa, Kazuo Makimoto, Tamio Yamauchi \\ (Kyoto University) \\ Shuichi Hida and Yoichi Takahashi \\ (Osaka Red Cross Hospital)
}

The detailed principle and theory of cell kinetics, which were derived from analysis by flow-micro-fluorometry, reveal significant implications for cancer chemotherapy. Bleo-VEMF'HA sequential synchronized chemotherapy has been established under the expectation that cancer cells will theoretically be synchronized first at the G2 phase and next at the $\mathrm{S}$ phase, according to cell kinetics.

Fifteen patients with head and neck cancer received this chemotherapy.

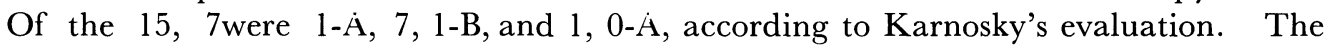
total response rate was $93 \%$. Two cases of malignant lymphoma showed complete remission.

Bleo-VEMF'HA sequential synchronized chemotherapy has been discussed on this theoretical base, and has been demonstrated to be a very effective therapy for head and neck cancer.

は じめに

頭頸部悪性腫瘍に対する化学療法は，現在までに数多く試みられている．最近では頭頸部悪性腫 瘍治療のため, 癌細胞の細胞回転を考慮した多剂併用同調化学療法が試みられるようになってい る. 癌細胞の細胞回転に関する知見は，近年著しく集積され，高本の行なった，Flow-microfluorouetry を用いた各種抗癌剂特質の解析結果は患性腫瘍治療にあたって示唆多い情報を呈供し ている ${ }^{12)}$. また, Wassermanの腫瘍発生部位からみた抗癌剂感受性に関する研究は, 抗癌剂選択 に関する重要な指針を与えている，以上のような聚近の癌化学療法についての知見を参照とし，我 々はVEMFAH 療法 ${ }^{6)}$ に Bleomycin を加えた, 同調化学療法を考案し, てれを用いて頭頸部悪 性腫焬の治療に試みた。以下，てれまでに得た経験を報告する。

*京都大学医学部耳鼻咽喉科学教室 (主任：桧 学教授)

**京都大学医学部泌尿器科学教室（主任：吉田修教授)

***大阪赤十字病院泌尿器科 


\section{治 療 対 象}

昭和 54 年 2 月より，大阪赤十字病院耳鼻科に おいて, 本法を施行した 20 例のうち離脱症例 5 例を除いた15例が，今回の報告の対象である. その内訳は, 上顎癌 4 例, 喉頭癌 4 例, 舌癌 2
例，その他 5 例である. 病理組織学的分類で は, 扁平上皮癌 12 例, 覀性リンパ腫 2 例, 腺様 のう胞癌 1 例である.

\section{投 与 方 法}

表 1 亿示すように，第 1 週目には連日 Methotrexate (MTX) $5 \mathrm{mg}$, Predonin 10mg の内 服投与，および Bleomycin (BLM) 5mg の筋 注を行なった。これに第 1 日目と第 4 日目に Vincristine (VCR) $1 \mathrm{mg}$ の静注を加えた。第 2 週初日に Endoxan (EX) $400 \mathrm{mg}$ の静注を行 ない，また第 2 週初日より F H 細粒（ 5 F U 誘 導体）の内服を開始し，乙れを第 5 週末まで続 けた。第 3 週初日に再び Endoxan 400mg の静
注，第 4 週初日に Adriamycin (ADM) 30mg の静注を行なった。補完療法として, 第 1 週よ り Krestin (PSK) 3. $0 \mathrm{~g}$ の内服投与を持続し, Picibanil (OK 432) の筋注を初回 $0.5 \mathrm{~K} \mathrm{E}$ よ り始め, 徐々に増量した後, 維持量 $5 \mathrm{KE}$ (3 日に 1 回)で持続した。乙の 5 週間を 1 course こした。最終 Course 終了後には維持療法とし て, F H細粒 600mg, PSK 3.0g, Picibanil $5 \mathrm{KE} / \mathrm{W}$ の投与を持続した。

表 I

1 Course は 5 週間としている.

Bleo-VEMF'HA 同調化学療法

(Synchronized sequential combination chemotherapy)
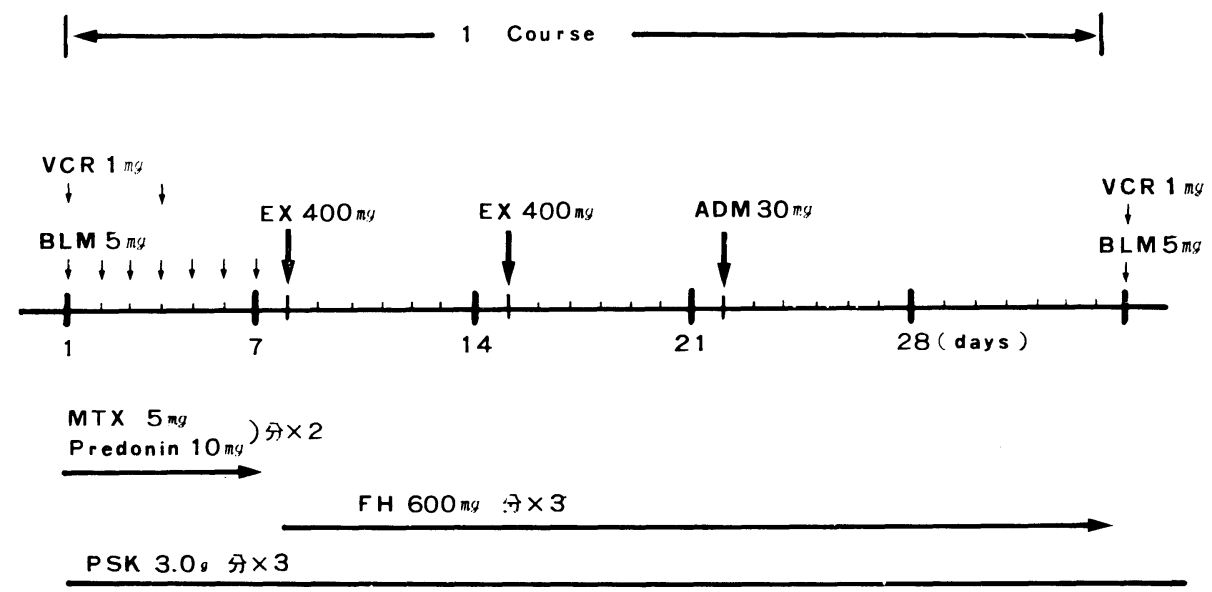

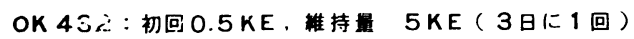

判 定 基 準

本治療法の効果判定は Karnofsky 分類（表 2) に従がって行なった。 との判定基準が適用
されない症例では自覚症状と他覚的所見の改善 度をもって判定した。 
表 2 Karnofsky の判定基準

\begin{tabular}{c|c|c|c}
\hline \hline & 自覚的改善 & 腫煬縮小 & 寛解期間 \\
\hline $0-0$ & $(-)$ & $(-)$ & \\
$0-\mathrm{A}$ & $(+)$ & $(-)$ & 1 力月未満 \\
$0-\mathrm{B}$ & $(-)$ & $(+)$ & " \\
$0-\mathrm{C}$ & $(+)$ & $(+)$ & $\prime \prime$ \\
$1-\mathrm{A}$ & $(+)$ & $(+)$ & 1 力月以上 \\
$1-\mathrm{B}$ & $(+)$ & $(+)$ & " \\
$1-\mathrm{C}$ & "常生活可能 & $>50 \%$ & " \\
& " & " & 1 年以上
\end{tabular}

\section{治 療 成 績}

表 3 に示してあるように，0-B 1 例， 1 A 7 例， 1-B 7 例であり，1-A 以上を有効 と考えると，その有効率は $93 \%$ となった。腫瘍 の大きさが50\%以上縮少したものは，15例中 7 例 $47 \%$ あ゙あた。 また 7 例中腫瘍の完全消失を みたものは 2 例である。この 2 例は悪性リンパ 腫症例であった。今回の対象には再発例が13例 含まれているが，そのうち12例に効果をみとめ た。これに対し新鮮例は 2 例であり，うち 1 例 は手術を拒否し, 他の 1 例は悪性リンパ腫であ ったが，いづれも 1 -Bを示し著効が認められ た. 組織学的分類との関係で, 上の治療法の効 果をみると, 次の成績がえられた。すなわち， 悪性リンパ腫に対する効果が最む優れており, 上述したように，2 例と屯腫瘍の完全消失を認 めている. 扁平上皮癌は 12 例中11例に効果がみ られ, 腺様のう胞癌の 1 例では $50 \%$ 以上の腫瘍 の縮少が認められた. 次に述べるのは卓効を示 した 4 症例である.

症例 2 (69才), 女性, 右上顎癌 (扁 平上皮癌, $\mathrm{T}_{2} \mathrm{~N}_{0} \mathrm{M}_{0}$ ). 昭和 53 年秋ごろより, 右鼻閉, 右鼻出血をきたすようになり, 昭和 54 年 3 月 9 日来院した. 手術をすすめたが承諾が 得られなかったので, 本療法を 1 course 施行 した. その結果, 症状が軽快し Waters 氏撮 影, 上顎断層撮影などの $\mathrm{X}$ 線撮影で治療前に
比し，腫瘍の著しい縮少を示す所見をえた（図 1 参照).

症例 3 (70才) 女性, 舌癌（扁平上 皮癌, $\left.\mathrm{T}_{2} \mathrm{~N}_{0} \mathrm{M}_{1}\right)$. 昭和52年12月ごろより, 舌 左側に腫瘍があるのに気づく．昭和53年 1 月 12 日に当科を受診し, 舌癌（扁平上皮癌）と診断 された. ${ }^{60} \mathrm{Co} 4600 \mathrm{rad}$ 照射の後, 舌腫瘍切除 術を受けた。局所再発はなかったが, 昭和 54 年 3 月29日, 胸部X線にて肺転移が発見された。 図 2 は治療前の胸部 X線であるが, 右側肺野中 央に転移病巣と考えられる陰影が認められる。 これに対し，上記の同調化学療法を行なうと, この転移病巣に著しい効果がみられた。すなわ ち, 図 3 ( 1 course 後), 図 4 (2 course 後) に示してあるように, 肺転移病单は漸次縮少 し, 治療11力月後には, 転移病巣はほとんど消 失した（図 5 参照).

症例10 (66才), 女性, 喉頭癌 (扁平 上皮癌, glottic $\mathrm{T}_{2} \mathrm{~N}_{2} \mathrm{M}_{1}$ ). 昭和 53 年末ごろよ り, 嗄声, 呼吸困難が増強し, 昭和 54 年 1 月 12 日来院した。診察の結果, 頸部転移, 肺転移, 腋窩転移を伴なう喉䫝癌であることが, 判明 し, 上記の同調化学療法を施行したところ, 喉 頭の腫瘍は縮少し頸部転移, 腋窩転移の消失を みた。また, 胸部 X線では治療後, 肺転移巣の 透亮像が認められるようになった (図6 参照). 
表 3 Bleo-VEMF' HA 同調化学療法の成績

\begin{tabular}{|c|c|c|c|c|c|c|c|c|}
\hline & 症 例 & 年 令 & 性 & 病 & 組織診断 & 前治療 & $ク ー ル$ & 効果 \\
\hline 1 & & (51 у.о.) & $\hat{o}$ & $\begin{array}{l}\text { 左上顎癌 } \\
\text { 左頸部転移 }\end{array}$ & 扁平上皮癌 & $\begin{array}{l}\text { 手術 } \\
60 \text { Co } 4500 \mathrm{R}\end{array}$ & 2 & $1-\mathrm{A}$ \\
\hline 2 & & $(69$ y. o.) & 우 & 右上顎癌 & 扁平上皮癌 & なし & 1 & $1-B$ \\
\hline 3 & & $(34$ y. о.) & $\hat{o}$ & $\begin{array}{l}\text { 右上顎癌 } \\
\text { 頸部・脑移 }\end{array}$ & 扁平上皮癌 & $\begin{array}{l}\text { 手術 } \\
\text { BM } 3 \text { クール } \\
60 \text { Co } 4600 R\end{array}$ & 2 & $1-\mathrm{A}$ \\
\hline 4 & & $(47$ y.о. $)$ & $\hat{\delta}$ & 左上顎癌 & 扁平上皮癌 & $\begin{array}{l}\text { 手術 } \\
\text { Bleo } 720 \mathrm{mg} \\
60 \mathrm{Co} 4800 \mathrm{R}\end{array}$ & 2 & $0-\mathrm{B}$ \\
\hline 5 & & (53 у.о.) & $\hat{\delta}$ & $\begin{array}{l}\text { 舌癌 } \\
\text { 頸部転移 }\end{array}$ & 扁平上皮癌 & $\begin{array}{l}\text { 手術 } \\
\text { BM } 2 \text { クール } \\
60 \mathrm{Co} 4600 \mathrm{R}\end{array}$ & 2 & $1-\mathrm{A}$ \\
\hline 6 & & (70 y.o.) & 우 & $\begin{array}{l}\text { 舌癌 } \\
\text { 肺転移 }\end{array}$ & 扁平上皮癌 & $\begin{array}{l}\text { 手術 } \\
60 \text { Co } 4600 R\end{array}$ & 1 & $1-\mathrm{B}$ \\
\hline 7 & & (74 y. o.) & $\hat{o}$ & $\begin{array}{l}\text { 喉頭癌 } \\
\text { 頸部転移 }\end{array}$ & 悪性リンパ腫 & なし & 2 & $1-B$ \\
\hline 8 & & (54 y. o.) & $\hat{o}$ & 喉頭癌 & 扁平上皮癌 & $\begin{array}{l}\mathrm{BM} 4 \text { タール } \\
{ }^{0} \mathrm{Co} 4600 \mathrm{R}\end{array}$ & 2 & $1-\mathrm{A}$ \\
\hline 9 & & (72 у. о.) & $\hat{o}$ & $\begin{array}{l}\text { 喉頭癌 } \\
\text { 頸部転移 }\end{array}$ & 扁平上皮癌 & ${ }^{60} \mathrm{Co} 4600 \mathrm{R}$ & 1 & $1-\mathrm{A}$ \\
\hline 10 & & $(66$ y.o.) & 우 & 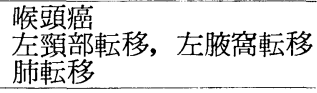 & 扁平上皮癌 & 手術 & 2 & $1-B$ \\
\hline 11 & & $(68$ y.o.) & 우 & $\begin{array}{l}\text { 右咽頭癌 } \\
\text { 右顎部転移 }\end{array}$ & 扁平上皮癌 & $\underset{60 \mathrm{Co} 5000 \mathrm{R}}{\mathrm{BM}}$ & 2 & $1-\mathrm{B}$ \\
\hline 12 & & (51 y.o.) & $\hat{o}$ & 右煩部粘膜腫瘍 & $\begin{array}{l}\text { 角华 } \\
\text { 扁平上皮癌 }\end{array}$ & $\begin{array}{l}\mathrm{BM} 3 \text { クール } \\
60 \mathrm{Co} 6600 \mathrm{R}\end{array}$ & 1 & $1-B$ \\
\hline 13 & & $(63$ y.о.) & 우 & $\begin{array}{l}\text { 右口蓋腫晹 } \\
\text { 右頸部転 }\end{array}$ & 扁平上皮癌 & $\underset{60 \mathrm{Co} 6000 \mathrm{R}}{\mathrm{BM}}$ & 3 & $1-\mathrm{A}$ \\
\hline 14 & & (38 у.о.) & $\hat{o}$ & 左口蓋腫煬 & 腺様のう胞癌 & ${ }^{60} \mathrm{Co} 4800 \mathrm{R}$ & 1 & $1-\mathrm{A}$ \\
\hline 15 & & (56 у.о.) & 우 & $\begin{array}{l}\text { 左扁桃腫痬 } \\
\text { 頸部転移 }\end{array}$ & 悪性リンパ腫 & $\underset{{ }^{\circ}{ }^{\circ} \mathrm{Co} 2800 \mathrm{R}}{\mathrm{B}}$ & 1 & $1-B$ \\
\hline
\end{tabular}

症例12

(51才)，男性，右煩部粘膜腫 瘍 (扁平上皮癌, $\mathrm{T}_{4} \mathrm{~N}_{0} \mathrm{M}_{0}$ ). 昭和 49 年 5 月ご ろより，右煩部粘膜に腫瘤を認めたが放置して いた．昭和51年 5 月 26 日に来院した際には，右 顎骨部に, 表面不整, 易出血性の約 $5 \mathrm{~cm} \times 4 \mathrm{~cm}$ $\times 3 \mathrm{~cm}$ 大の腫瘤を認めた。 その組織学的所見は 扁平上皮癌である。乙の所見に基づいて， ${ }^{60} \mathrm{Co}$ 外照射を行ない, 全線量 $6600 \mathrm{rad}$ を加えた。
その結果, 腫瘤の縮少をみた。しかし，腫瘤の 増大が再びみられるようになったので，昭和 53 年 6 月より BM療法を 3 course 施行した。 そ の結果, 腫瘤は縮少した。しかし，日を経ずし て再び増大傾向をみたので, 同調化学療法に切 りかえて, 治療を開始した。乙の療法の結果, 図 7 に示してあるように, 腫瘤は著しく縮少し た。 

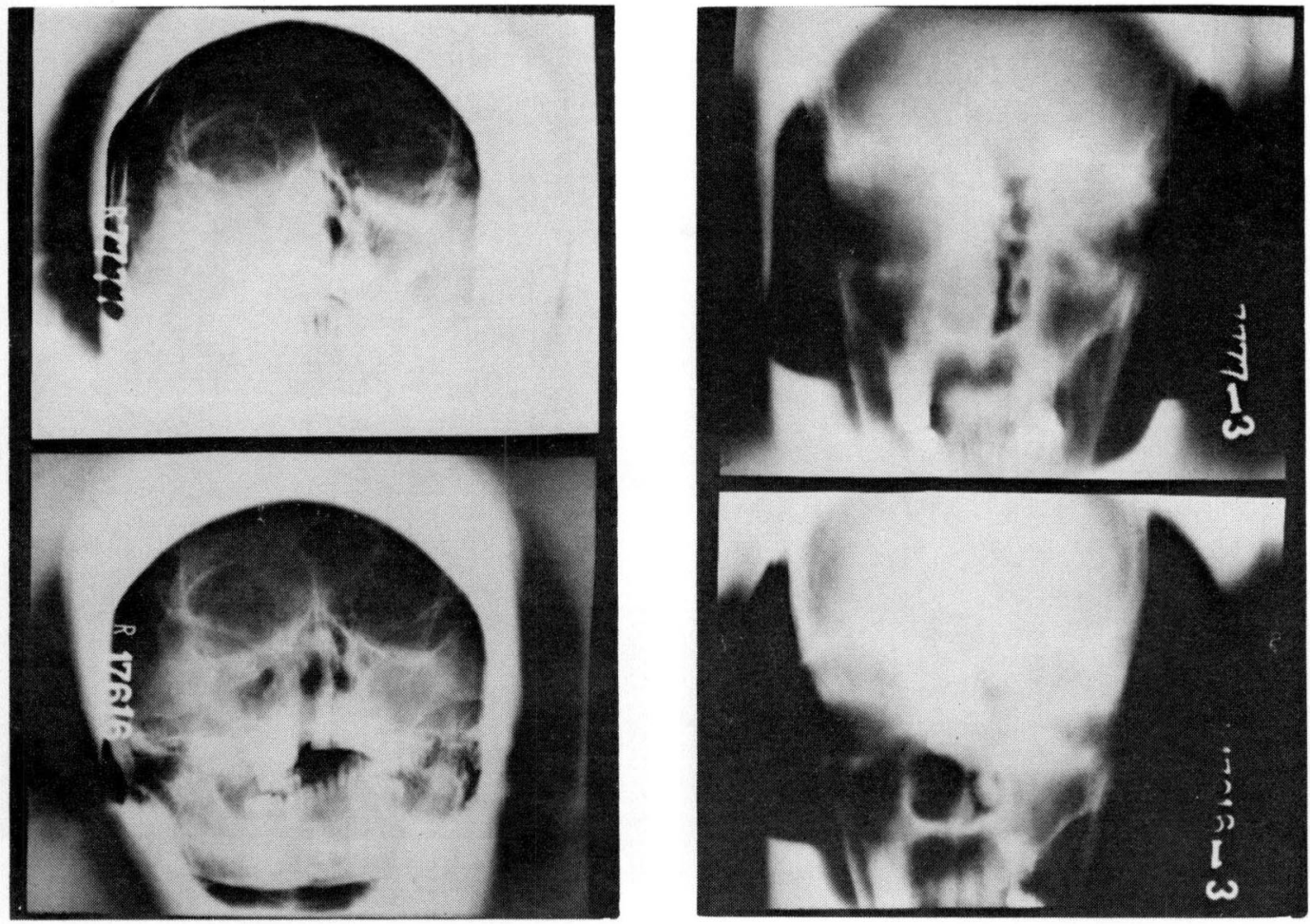

図 IWaters 氏撮影，上顎断首撮影において治療前（上）に此へ，治療後（下）は腫瘍の著明 な縮小を示している. 右上額洞の透亮像, 右鼻内の腫啺の消失がみられる,

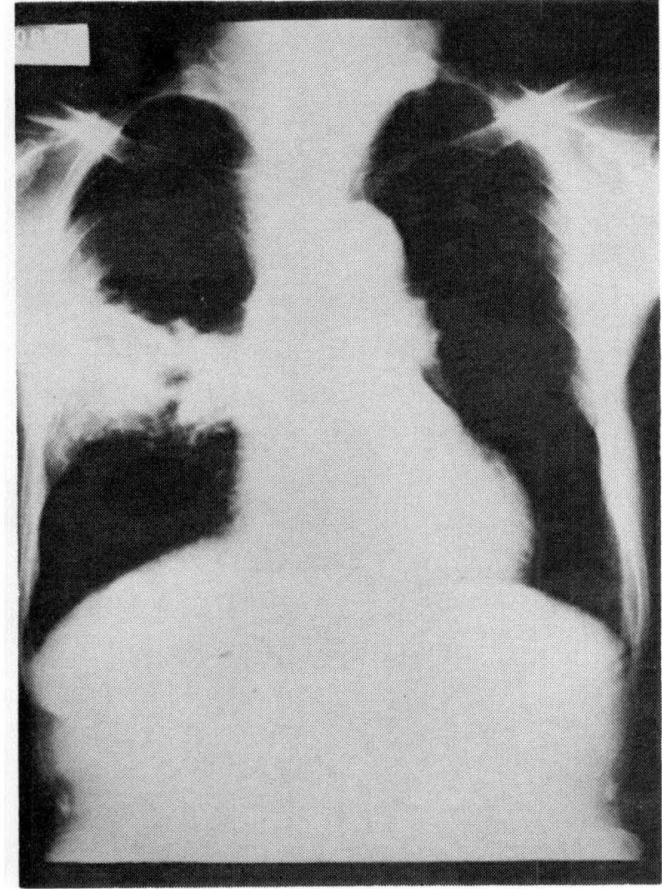

図 2 (治療前) 右肺野中央に転移巣を認める.

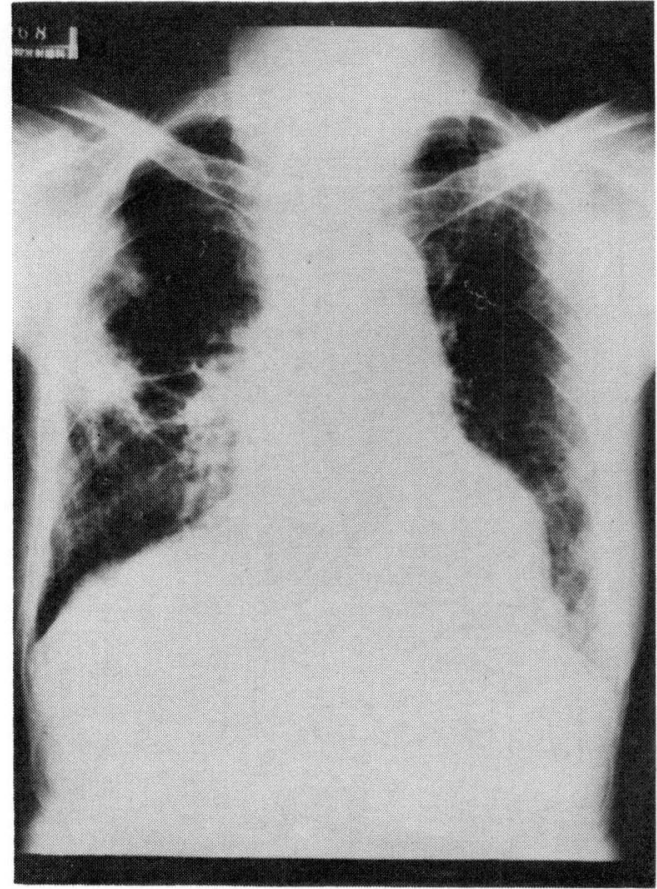

図 3 (1 Course のち) 


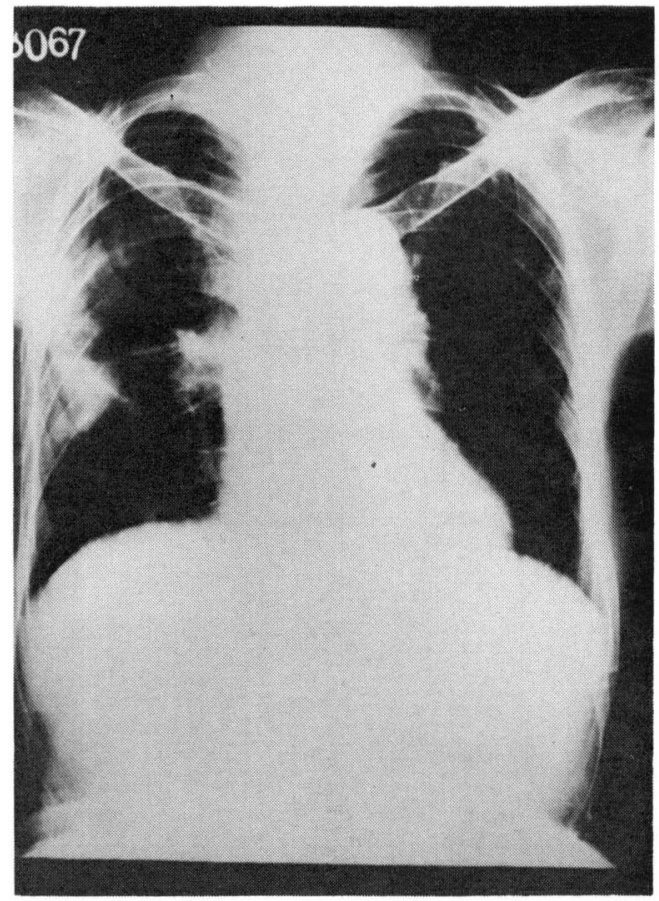

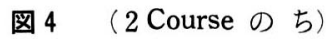

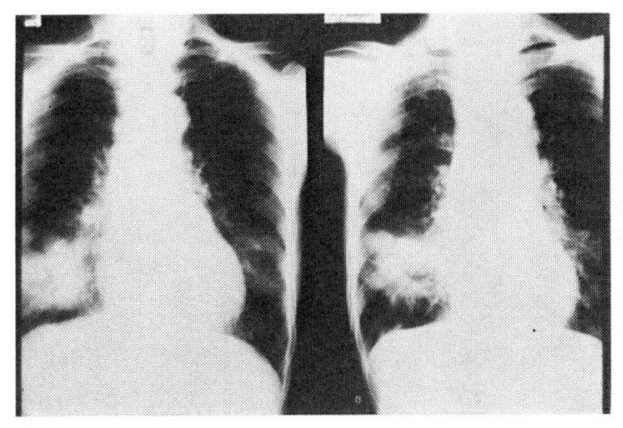

治療前

治坆後

図 6 治療後の胸部レ線では転移巣の中心に 透亮像を認める.

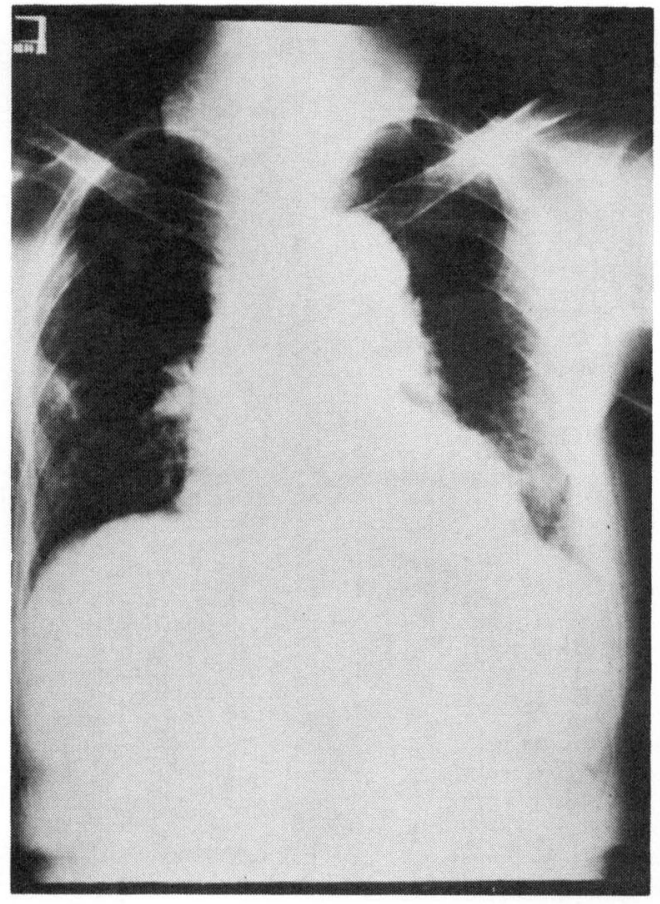

図 5 (11力月後) 図 3 亿恝められた転移巣は ほとんど消失した。

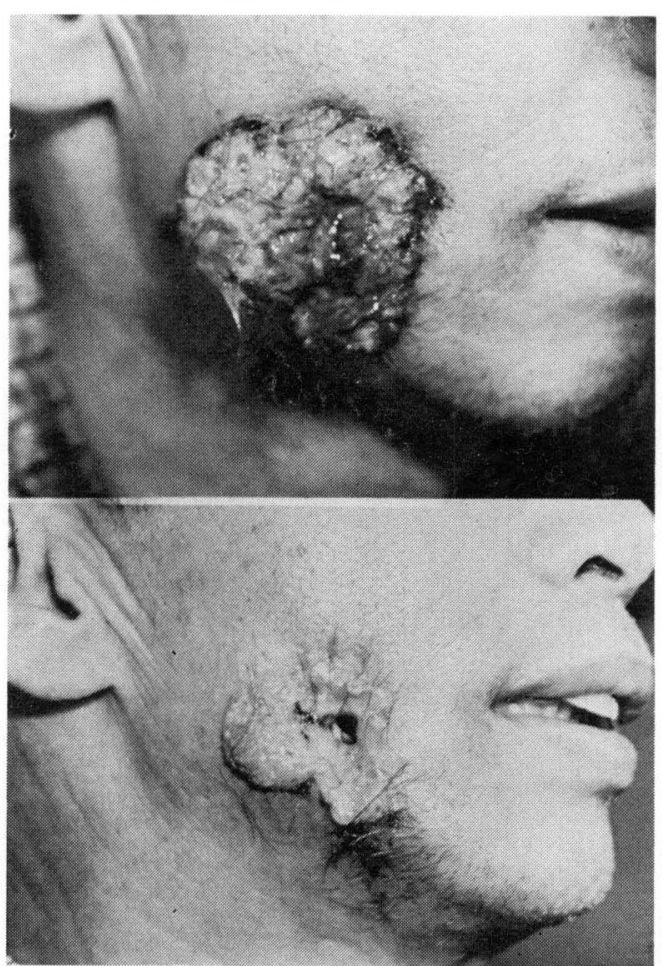

図 7 治療前（上）に比べ治療後（下）に著しい 腫煌の縮少を認める。 


\section{副作 用}

同調化学療治の結果，骨髅機能の抑制，口内 炎の発生, 食欲不振, 全身倦急感, 脱毛が症例 の大多数に認められた。また。高度の副作用の ために，一時療法を中断せざるをえないものが 15例中 7 例にみられた。なお，この 7 例のうち 5 例には骨髄機能の抑制が，2例にはかなり強 い全身倦㤐感がみられている。なお，口内炎の 予防には，フラビタンの内服，MTXの毒性に 対しては，ロイコボリンあるいはフォリアミン

\section{考}

Flow-micro-fluorometry（F.M.F) の導入 により抗癌剂の細胞回転に及ぼす影響に関する 研究は，ますます系統的に行なわれるようにな っている。本装置を利用すれば細胞集団のD N $\mathrm{A}$ 量の分散分布を瞬時のうちに，ヒストグラム として表現可能であり, 細胞回転の解析は極め て容易に行なえる ${ }^{1)}$. 高本らは, 人羊膜由来の 単層培養細胞 F L株を用いた実験で, 各種抗癌 剂が Cycle progression へ関与する過程を F.M.F.を用いて明らかにしている。乙の実験 は, 固型癌に対する抗癌剂の関与についてのモ デル実験と考えてよく，その成果は，ヒトの悪 性腫瘍に関する多剂併用化学療法の有用性につ いて貴重な手がかりを与えている．図８は抗癌 剂を用いない場合のDNAヒストグラムと各細 胞周期との関係を，F.M. F. を用いて示した あのである. 図示するように 2 峰性のヒストグ ラムが得られ，2 Cには大きなピークが，4 C には小さなピークがみられる. 更に，2 Cには $\mathrm{G}_{0}$ または $\mathrm{G}_{1}$ 細胞群が， $4 \mathrm{C}$ には $\mathrm{G}_{2}$ および $\mathrm{M}$ 期細胞群が示され, この両群の間には $\mathrm{S}$ 期細胞 群が示されている. これに対し, 図 9 〜 13には 各種の抗癌剂, すなわち, 代謝拮抗剤, ビンカ ・アルカロイド製剂, 抗生物質性抗癌剂, アル キル化剂などを用いた際の成績を示してある. 図示するように, それぞれの抗癌剤の濃度によ って，細胞回転は異なる態度を示すことが明ら
の投与を行なった。骨髄機能抑制を来した症例 では血清カリウム值の低下を伴なっているもの が多い。このような症例には，カリウム製剂を 投与した。その結果，血液所見の改善が認めら れている，上記の様な副作用が括てるてとが知 られているので, 今回ての療法を行なう場合に も週 2-3 回の血液検查, 週 1 回の血清化学的 検査, 検尿, 月 1 回の胸部 $\mathrm{X}$ 線撮影, 心電図検 查を行なっている.

\section{按}

かにされた。

さて, 今回採用した同調化学療法では, 第 1 週にはMTX, B L M, V C Rが組み合わせて 投与されている。乙れら薬剂を，上記の投与量 及び，投与方法で与える場合の血中濃度を考え ると, MT Xは図 9 のの濃度, VCRは図 10 の $\mathrm{A}$ の濃度, B LMは図11のBの濃度に比定し うる. 従って, Cell progressnは図12のように

\section{DNA Histogram}

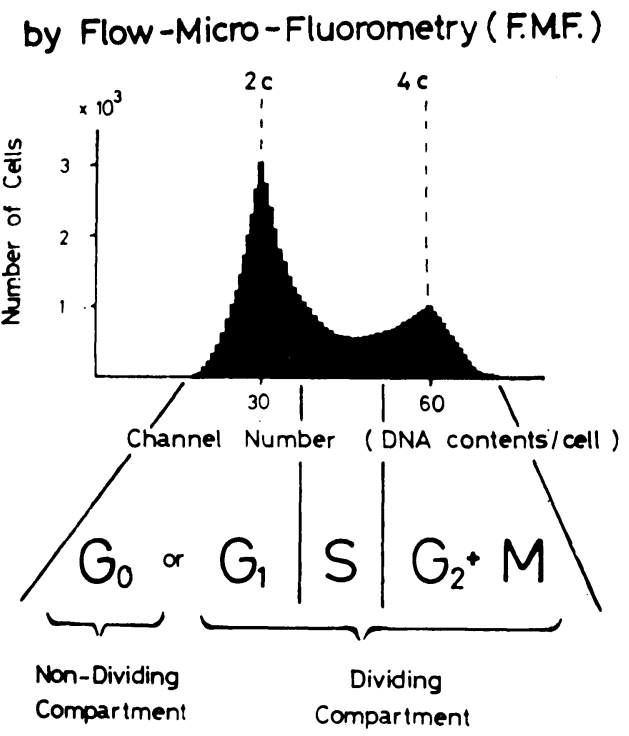

F. M. F.によるDNA ヒストクラムと各細胞周 期との凰係

図 8 (高本ら $\left.{ }^{2)}\right)$ 


\section{Effects of Antimetabolites on Cell Cycle Traverse}
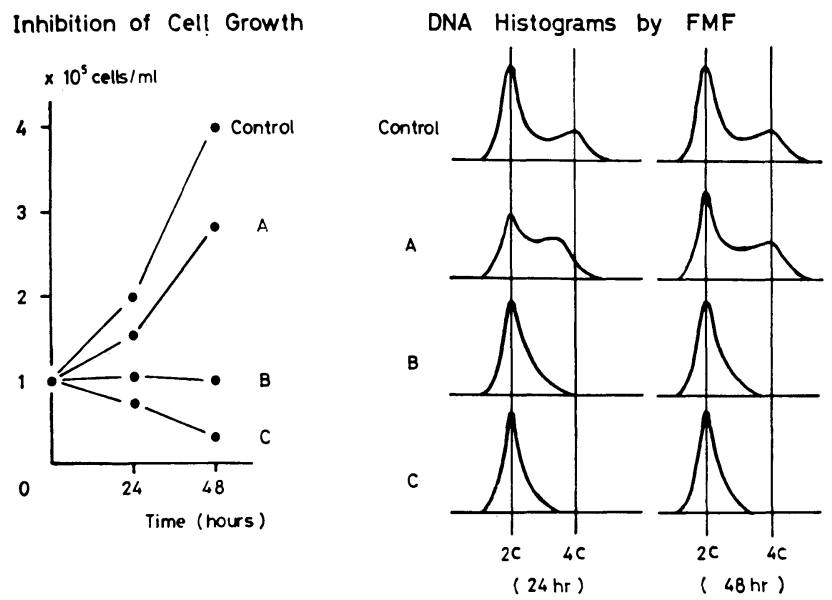

図 9 (高本ら $\left.{ }^{2)}\right)$ F.M.F.による代謝拮抗剤の細胞回転 におよぼす影響（模式図）

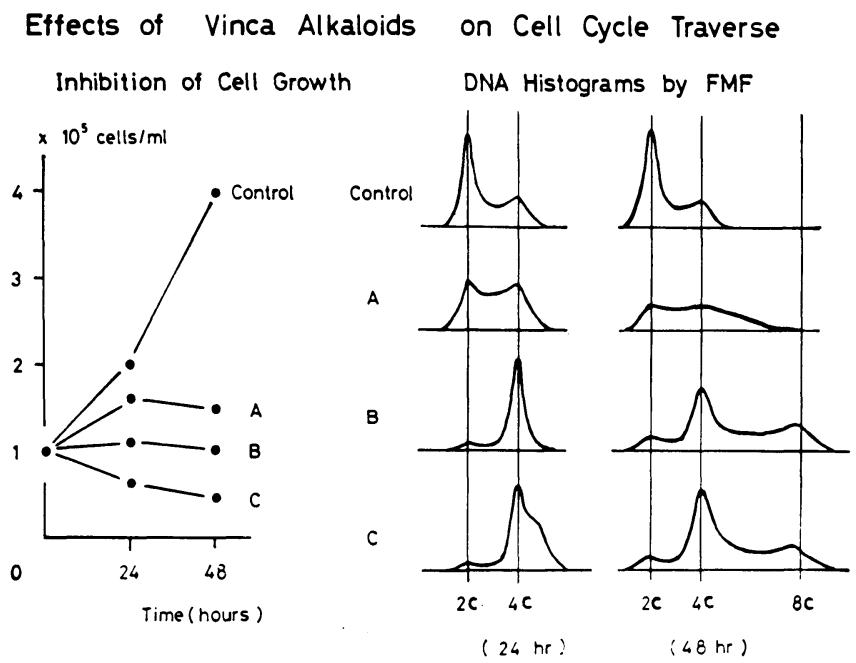

図10 (高本ら 2) ${ }^{2}$ F.M.F.によるビンカ・アルカロイド の細胞回転におよぼす影響（模式図）

$\mathrm{G}_{2}$ block（あるいは accumlation）を示すと考 えてよい，すなわち，投与第 1 週では，MTX はD N A 合成阻害作用によって， S 期延長をは かるものと考えられる2． ここで， $\mathrm{S}$ 期感受性 の強いVCRを投与すれば， total mass を減 ずるとともに，核分裂阻止をもたらすことにな る ${ }^{8)}$ ままた, 同時にB LMの連続投与を所なえ
ば, $\mathrm{G}_{2}$ 蓄積作:用により癌細胞群は $\mathrm{G}_{2}$ 期に block されることになる ${ }^{910)}$. (図13参照) こてで，第 2 週初めに EX（投与量及び静注法によるため 浱度は図12のCに比定しうる）を用いる理由 は，蓄積された $\mathrm{G}_{2}$ 細胞群に，この楽剂を強力 に作用させ，腫瘤を減少させ，功同時に S 期 の延長をむたらすためである，続いて，投与す 
Effects of Antibiotics on Cell Cycle Traverse

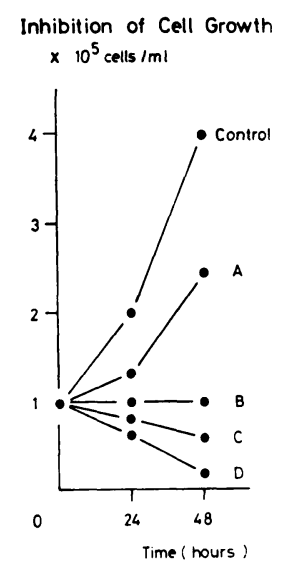

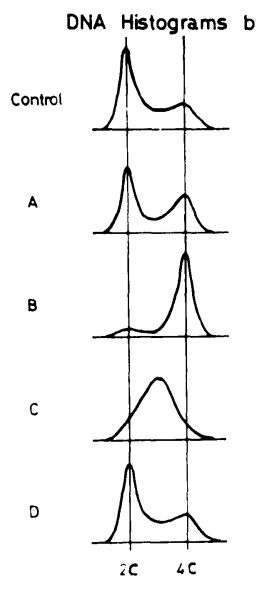

(24 hr)

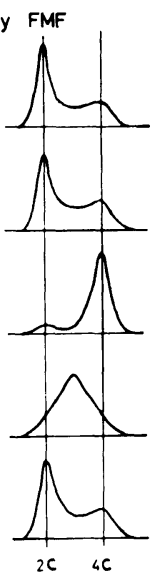

$(48 \mathrm{hr})$

図II（高本ら $\left.{ }^{2)}\right)$ F.M. F.に上る抗生物質の細胞回 転におよばす影響（II）（模式図）

Effects of Alkylating Agents on Cell Cycle Traverse
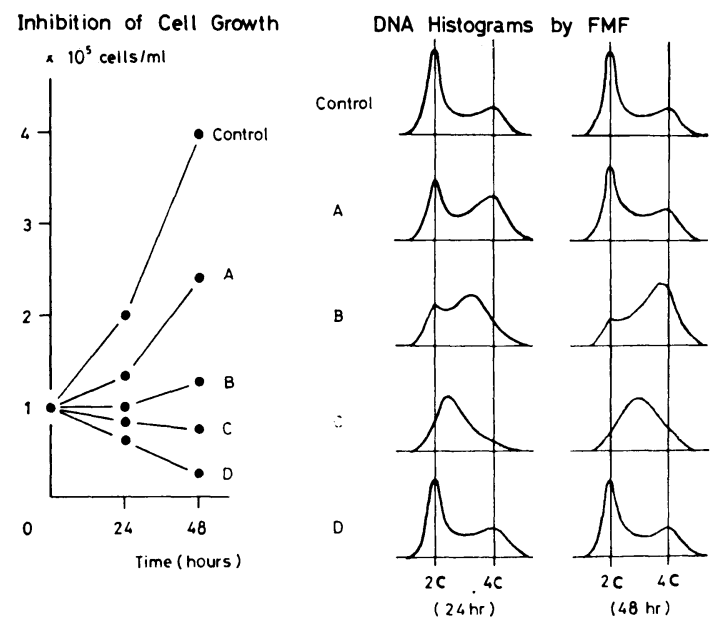

図12 (高本ら $\left.{ }^{2)}\right)$ F.M.F.によるアルキル化剂の細胞 回転におよぼす影響（模式図）

る F H（投与量と及び, 内服投与による濃度か ら図 9 の濃度 A に比定しうる）はS 期に作用す るものであり，腫瘤を減少させつつ， $\mathrm{S}$ 期の増 加をはかるあのと考えてよい(11). 第 3 週の初め に再び $\mathrm{EX}$ X使用すれば， $\mathrm{S}$ 期の延長と増加を 期待できる. 更に 4 週目に特に $\mathrm{S}$ 期感受性の強 いA DMを作用させ, 同期に S 期の進行を停止
させたまま ${ }^{1213)}$ ，F Hを作用させると腫瘤の減 少と $\mathrm{S}$ 期の延長をむたらすことが可能となる. 以上が今回, 考按した Bleo-VEMF'HA 同調 化学療法の理論的根拠である (図 13 参照).

さて, 進行性乳癌に対し, 1969 年 Cooper ら ${ }^{16)}$ は, VCR, EX, 5FU, MTX, Predonisone を用いた多剂併用療法を行ない, $88 \%$ の 
Bleo-VEMF'HA 同調化学法の理論（模式図）

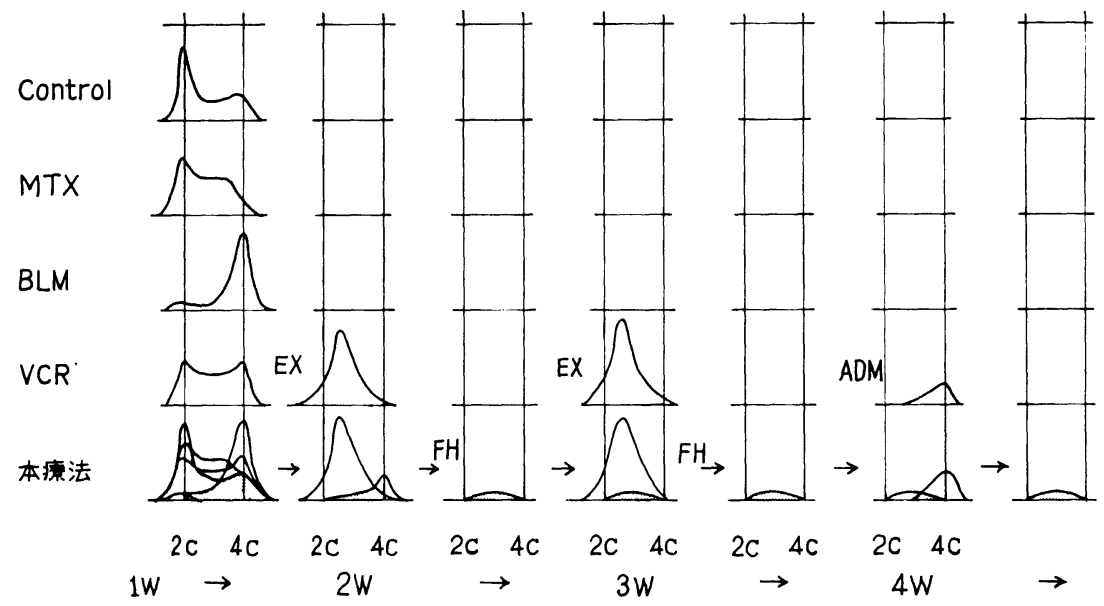

図13 本療法で残る細胞群は黒い部分である.腫煌の縮少を確すために週を重ねるに つれて，模式的に小さく示している．実際のF.M.F.ではヒストグラムの面 積は変化しない。

完全寛解をみたと述べている．1978年，星野 ら ${ }^{6)}$ は, Cooper の用いた 5 剂にA DMを加え た， 6 者併用の V EMF A H 療法を，再発性 進行乳癌に試み, 効果判定可能な 6 例全例に著 明な抗腫瘍効果を認めている，共著者の山内 は, 乳癌と前立腺癌の相似性に注目し, これら 6 者併用薬剂の有効性を期待した。また，てれら 6 者併用楽剂は, Wassermann, Carter ${ }^{7)} ら の$ 研究により頭頸部悪性腫瘍にもすぐれた感受性
を示すととが判明している。（表 4 参照）我々 は，乙れらにB LMを加え 7 者併用とし，高本 らの解析結果に基づき, $\mathrm{G}_{2}$ 期, $\mathrm{S}$ 期同調化学 療法を組み立ててた。

すでに，頭頸部領域で行なわれた同調化学療 法には Price-Hill 法 ${ }^{14)}$, Livingston ${ }^{{ }^{15}}{ }^{15)}$, B

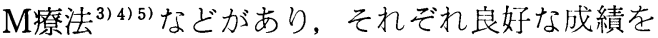
収めている。我々が考案した, Bleo-VEMF'HA 同調化学療法を頭頸部領域で応用した場合は,

表 4 諸剤の乳癌と頭頸悪性腫瘍に対する感受性

Breast cancer

\begin{tabular}{|c|c|c|c|}
\hline Drugs & Activity & $\begin{array}{l}\text { No. of responses/ } \\
\text { No. of evaluable patients }\end{array}$ & $\begin{array}{l}\text { Response } \\
\text { rate \% }\end{array}$ \\
\hline $\mathrm{EX}$ & $H$ & $182 / 529$ & 34 \\
\hline $5-\mathrm{F} \mathrm{U}$ & $H$ & $324 / 1263$ & 26 \\
\hline MT X & $H$ & $120 / 356$ & 34 \\
\hline V C R & $H$ & $47 / 226$ & 20 \\
\hline V B L & $H$ & $19 / 95$ & 20 \\
\hline A DM & $H$ & $67 / 193$ & 35 \\
\hline B L M & - & $3 / 26$ & 12 \\
\hline
\end{tabular}

Head and neck cancer (all types)

\begin{tabular}{c|c|c|c}
\hline Drugs & Activity & $\begin{array}{l}\text { No. of responses/ } \\
\text { No. of evaluable patients }\end{array}$ & $\begin{array}{c}\text { Response } \\
\text { rate }\end{array}$ \\
\hline M T X & ++ & $298 / 630$ & 47 \\
B L M & ++ & $24 / 158$ & 15 \\
E X & + & $28 / 77$ & 36 \\
5- F U & + & $18 / 118$ & 15 \\
V B L & + & $10 / 35$ & 29 \\
V C R & N E & - & - \\
A D M & + & $13 / 67$ & 19
\end{tabular}

Todd H. Wasserman et al. (Cancer chemotherapy Reports part 3 Vol. 6 No. $2: 399,1975$ ) 
前述のように悪性リンパ腫の他, 扁平上皮癌や 腺様のう胞癌にも効果がみとめられた。また， 本療法を共著者が泌录器科領域の悪性腫瘍に応 用したとてろ，以下のような成績をえている． すなわち, 前立腺癌（6例）では $1-\mathrm{C}$ が 1 例, 1-Bが 1 例, 1-Aが 1 例, 0 - $\mathrm{C}$ が 3 例であった。 また, 膀胱癌（移行上皮癌 3 例, 印環細胞癌 1 例) では，1-Bが 1 例， 1 - $\mathrm{A}$ が 2 例， $0-\mathrm{C}$ が 1 例であった。腎孟癌（移行 上皮癌 1 例)では，1-Bであり，睪丸腫瘍(奇 形癌 1 例）では 1 - A であり，子宮頸癌（扁平 上皮癌 1 例）では 1 - $\mathrm{A}$ であり，皮膚扁平上皮 癌 1 例では 1 -Bであった。すなわち，全症例 14例中10例に, 乙の療法の有効性が確かめら れ，その有効率は $71 \%$ あっあた。
これまでのところ，頭頸部悪性腫瘍に対する 化学療法は手術的治療, 放射線療法などでは, 制御不可能と判定された, 進行癌症例に行なわ れることが多い，從って，化学療法に対する腫 瘍の反応性は低下している場合が，多いと考え てよく，その効果は期待するほど大ではない. この問題をよく解するためには, 今後, 本療法 のもつ副作用の軽減をはかるとともに，新鮮例 への応用を積極的に試みるほかない. 今後, 乙 の方向への努力を払い，今回，採用した同調化 学療法が, これまでに報告されている，他の多 剂併用同調化学療法と, どの点で相違するの か，また，その優劣はどのようなものであるか などを検討したいと考えている。

\section{む す び}

$\mathrm{G}_{2}, \mathrm{~S}$ 期に同調させた, Bleo-VEMF'HA 同調化学療法を考案し，乙れを頭頸部悪性腫瘍15例に 施行した。その結果, 有効率 $93 \%$ の好成績を得た。とくに悪性リンパ腫 2 例には完全寛解がみら れ, この種の症例への本療法の有用性が確かめられた。また, 扁平上皮癌12例中 11 例には腫瘍縮少効 果がみられ, 腺様のう胞癌の 1 例には $50 \%$ 以上の腫煬縮少が認められた。従って, その副作用防止 策を考案し,さらに新鮮例に対しての療法を応用すれば, その成果は一一層, 増大するむのと考えた。

稿を終えるに臨み, 御指導ならびに御校閲を賜わった京都大学耳鼻咽喉科学教室主任桧 学教授に深謝します. 本論文の要旨は，第41回耳鼻咽喉科臨床会総会において発表した（昭和54年10月10日）

\section{参 考 文 献}

1）太田和雄，高本滋，御供泰治：D N A 瞬間自動測 定装置. 癌と化学療法 $4: 179 \sim 185,1977$.

2) 高本滋, 太田和雄：F.M.F.几上る細胞回転と癌 化学療法. 癌と化学療法 $5: 729 \sim 736,1978$.

3 ) 宮本忠昭, 高部吉庸, 渡辺道典, 寺島東洋三：ブ レオマイシンとマイトマイシンの連続的併用（B 一M）療法による末期子宮頸癌の治療成績につい て. 癌と化学療法 $4: 273 \sim 291,1977$.

4) 犬山征夫, 中島康夫, 浅岡一之, 堀内正敏, 高崎 敬, 小津雷助, 松川純一: 頭頸部悪性腫煌に対す る Bleomycin と Mitomycin の連続的併用療法 （B-M療法）の効果について. 耳鼻臨床 70 ： 721 727, 1977.

5 ）大野政一, 昇貞夫：頭頸部悪性腫煌に対するブレ
オマイシンとマイトマイシンの連続的併用療法の 効果について. 耳鼻 $23: 499 \sim 504,1977$.

6 ）星野章, 名倉英一, 大杉順一, 大口貞雄, 橋爪真 言, 山崎健之, 広田敏行, 新実藤吉: 再発進行乳 癌に対するAdriamycin を含む6 者併用 “VEMFAH” 療法の効果. 癌と化学療法 $5: 215 \sim 222$, 1978.

7 ) Wasserman, T. H., Comis, R. J., Goldsmith, M., Handelsman, H., Penta, J. S., Slavik, M., Soper, W. T., and Carter, S. K. : Tabular analysis of the clinical chemotherapy of solid tumors. Cancer Chemotherapy Reports 6 : 399 419, 1975.

8 ) Madoc-Jones, H. and Maruro, F. : Irterphase 
actio of Vinblastine and Vincristine differences in their lethal action through the mitotic cycle of cultured mammalian cells. : J. Cell physiol. $72:$ 185 196, 1968.

9 ) Barranco, S. C. and Hunphery, R. M.: The effect of Bleomycin on survival and progression in chinese hamster cells in vitro, Cancer Res. 31 : 1218 1223, 1971.

10) Tobey, R. A. : Arrest of chinese hamster cells in $G_{2}$ following treatment with the antitumor drug bleomycin. J. Cell. physiol. 79 : 259 266, 1972.

11) Bhuyan, B. K., Blowers, C.L., Neil, G. L., Bono, V. H., and Day, K. J. : Partial synchronization of L 1210 Cells by 5-fluouracil and its use in drug Combinations. Cancer Res. $37: 3204 \sim 3208,1977$.

12) Kim, J. H., and Kim, S. H., : Lethal effects of Adriamycin of the division cycle of Hela cells. Cancer Res. 32 : 323 325, 1972.
13) Krishan, A., and Frei E. III. : Effect of Adriamycin on the cell cycle transvers and Kinetics of cultured human lyophoblasts. Cancer Res. $36: 143 \sim 150,1976$.

14) Price, L. A. and Hill, B. T. : A kinetically based logical approach to the chemotherapy of head and neck cancer. Clin. Otolayng 2 : 339 345, 1977.

15) Livingston, R. B., Bodey, G. P. Gottlieb J. A., and Frei, E. III : Kinetic Scheculing of vincristine and bleomycin in patients with lung cancer and other malignant tumors. Cancer chemotherapy, Rep. $56: 183 \sim 195,1972$.

16) Cooper, R.: Combination chemotherapy in hormone resistant breast cancer. Proc. Am. Asssoc. Cancer Res. 10:15, 1969.

原稿到着：昭和 56 年 2 月 17 日

別刷請求先：大川正直 巴606 京都市左京区聖護院川原町53 京都大学医学部耳鼻咽喉科学教室 